\title{
PENANGANAN KEKERASAN ANAK BERBASIS MASYARAKAT
}

\author{
Oleh: \\ Uswatun Hasanah $^{1}$, Santoso Tri Raharjo ${ }^{2}$ \\ 1. Mahasiswa Magister Program Studi Kesejahteraan Sosial FISIP Universitas Padjadjaran \\ 2. Staf Pengajar pada Departemen Kesejahteraan Sosial FISIP Universitas Padjadjaran \\ Email : uswatun.ks09@gmail.com; santoso.tri.raharjo@unpad.ac.id
}

\begin{abstract}
ABSTRAK
Anak merupakan aset bangsa yang kelak akan memelihara, mempertahankan, serta mengembangkan kekayaan hasil perjuangan bangsa. Kekerasan terhadap anak menjadi fenomena yang tidak ada habisnya. Kasus dan korbannya selalu meningkat setiap tahunnya. Kekerasan dapat terjadi di lingkungan dalam maupun luar keluarga. Anak yang menjadi korban kekerasan tentu akan mengalami trauma baik fisik maupun psikisnya. Anak yang mengalami kekerasan di masa lalunya akan berpotensi untuk melakukan tindak kekerasan (pelaku) ketika mereka dewasa. Anak yang menjadi korban kekerasan perlu mendapatkan perhatian khusus dan penanganan secara khusus yang melibatkan orang tua, keluarga, pemerintah, dan peran serta masyarakat. Dibutuhkan strategi dalam penanganan kekerasan terhadap anak. Strategi yang dilakukan harus mampu mencegah dan menangani tindak kekerasan. Dalam hal ini dibutuhkan kerjasama dari berbagai pihak agar strategi yang dilakukan berjalan secara holistik dan komprehensif.
\end{abstract}

Kata Kunci : Kekerasan Anak, Strategi Penanganan Kekerasan

\begin{abstract}
Chidren are an asset of the nation who would maintain, retain, and develop the wealth and national struggle. Violence against children became a phenomenon that is endless. Cases and victims is increasing every year. Violence can occur in the environment inside and outside the family. Children who are victims of violence will certainly experience both physical and psychological trauma. Children who have experienced violence in the past would have the potential for violent action (actors) when they are adults. Children who are victims of violence need special attention and special handling involving parents, family, government, and community participation. Strategy is needed in the handling of child abuse. Strategies that do need to be able to prevent and deal with violence. In this case it takes the cooperation of various parties in order to run the strategy undertaken holistically and comprehensively.
\end{abstract}

Keyword : Child Abuse, Violence Treatment Strategies 


\section{PENDAHULUAN}

Anak merupakan asset bangsa sekaligus amanah yang kelak akan memelihara, mempertahankan, serta mengembangkan kekayaan dan perjuangan bangsa. Oleh karena itu anak harus sehat, baik secara jasmani maupun rohani agar terjamin tumbuh kembang mereka sesuai dengan hakhaknya. Setiap anak pada hakikatnya membutuhkan perawatan, perlindungan, pengajaran, dan kasih sayang oleh orang-orang dewasa (orang tua terutama), agar menjamin kebutuhan fisik, mental, sosial dan spiritual mereka. Tidak dapat dipungkiri bahwa orang tua memperoleh tangung jawab pertama dan utama yang berkewajiban memenuhi hak dan kebutuhan anak mereka.

Semua anak memiliki hak untuk dilindungi dari kekerasan, eksploitasi dan pelecehan. Oleh karena itu orang tua dan orang dewasa (termasuk pemerintah) berkewajiban melindungi mereka. Hal ini sesuai dengan yang tercantum di dalam Undang-Undang tentang Perlindungan Anak yaitu UU Nomor 23 Tahun 2002 pada Bab III Pasal 13, yang berbunyi :

"Setiap anak selama dalam pengasuhan orang tua, wali, atau pihak lain mana pun bertanggung jawab atas pengasuhan, berhak mendapat perlindungan dari perlakuan : diskriminasi, eksploitasi baik ekonomi maupun seksual, penelantaran, kekejaman, kekerasan, dan penganiayaan."
Pernyataan tersebut memiliki arti bahwa anak sudah seharusnya mendapatkan perlindungan dari para pihak yang memberikan pengasuhan. Namun pada kenyataannya, saat ini orang tua sering melupakan fungsi dan peranan mereka sehingga seringkali para orang tua tidak menyadari mereka telah melakukan perilaku kekerasan pada anaknya. Bahkan ada orang tua yang tidak tahu bahwa anaknya sebenarnya sedang mendapatkan perilaku kekerasan dari pihak luar atau lingkungannya. Fenomena kekerasan terhadap anak saat ini selalu menjadi topik utama dalam pemberitaan (nasional.kompas.com)

Kekerasan terhadap anak menjadi fenomena yang tidak ada habisnya. Kasus dan korbannya selalu meningkat setiap tahunnya. Seperti data yang didapatkan dari Komisi Perlindungan Anak Indonesia (KPAI), sebagai berikut :

Tabel 1.1 Data Kasus Kekerasan Terhadap Anak Tahun 2010-2015

\begin{tabular}{|c|c|c|c|c|c|c|}
\hline $\begin{array}{c}\text { KEKERASAN } \\
\text { PADA } \\
\text { ANAK }\end{array}$ & 2010 & 2011 & 2012 & 2013 & 2014 & 2015 \\
\cline { 2 - 7 } & 171 & 2179 & 3512 & 4311 & 5066 & 6006 \\
\hline
\end{tabular}

Sumber : Laporan Bulanan KPAI Kasus Pengaduan Anak Berdasarkan Klaster Perlindungan Anak

Tabel 1.2 Data Korban Kekerasan Anak Tahun 2012-2015

\begin{tabular}{|c|c|c|c|c|}
\hline $\begin{array}{c}\text { KORBAN } \\
\text { KEKERASAN } \\
\text { ANAK }\end{array}$ & 2012 & 2013 & 2014 & 2015 \\
\cline { 2 - 5 } & 422 & 750 & 866 & 1256 \\
\hline
\end{tabular}

Sumber : Laporan KPAI 
Dari data kasus yang di dapatkan dari laporan KPAI, data tersebut menjelaskan bahwa kasus kekerasan terhadap anak mengalami peningkatan setiap tahunnya. Begitupun dengan jumlah korban, dari data kasus Anak Berhadapan Dengan Hukum yang menjadi korban jumlahnya tertera pada tabel di atas yang setiap tahun pun mengalami peningkatan jumlah korban. Dari laporan data korban diatas, sisanya yang termasuk dalam laporan data kasus adalah pelaku kekerasan anak.

Data korban di atas jelas menggambarkan bahwa banyaknya anak yang mendapatkan perilaku kekerasan baik dari lingkungan dekat (orang tua, saudara kandung, keluarga) maupun lingkungan luar (sekolah, teman sebaya, tetangga, masyarakat). Kekerasan dapat terjadi di lingkungan dalam maupun luar keluarga. Kekerasan yang terjadi di dalam lingkungan keluarga seringkali terjadi karena ketidakharmonisan keluarga seperti tingkat stress yang tinggi, kurangnya komunikasi, kurangnya pengetahuan tentang pengasuhan yang baik, tidak mendengarkan keinginan anak sehingga memposisikan anak harus "nurut" dengan orang tua sehingga orang tua seringkali mengatasnamakan "kekerasan" sebagai usaha untuk "mendidik". Kekerasan yang terjadi di luar terjadi karena keterbatasan yang dimiliki anak, kurangnya kontrol orang tua, sekolah, tetangga dan aparat setempat, hilangnya nilai dan norma yang ada di masyarakat, tidak adanya akses tempat pengaduan tindak kekerasan di sekitar tempat tinggal, dan kurangnya pemahaman mengenai cara mendidik anak. (Cynthia Crosson-Tower, Child Abuse And Neglect, 65 : 2002)

Anak yang menjadi korban kekerasan tentu akan mengalami trauma baik fisik maupun psikisnya. Anak yang mengalami kekerasan di masa lalunya akan berpotensi untuk melakukan tindak kekerasan (pelaku) ketika mereka dewasa. Oleh karena itu anak yang menjadi korban kekerasan perlu mendapatkan perhatian khusus dan penanganan secara khusus yang melibatkan orang tua, keluarga, pemerintah, dan peran serta masyarakat. Sesuai yang tercantum pada pasal 20 Undang-Undang Nomor 23 Tahun 2002 tentang Perlindungan Anak adalah : "Negara, pemerintah, masyarakat, keluarga dan orang tua berkewajiban dan bertanggungjawab terhadap penyelenggaraan perlindungan anak."

Dari pasal diatas, terlihat mengenai bahwa setiap warga Negara wajib ikut sera berperan dalam penyelenggaraan perlindungan anak. Jadi ketika ada kasus kekerasan terhadap anak, maka sudah menjadi perhatian dan tanggungjawab setiap warga Negara. Berdasarkan kondisi tersebut, maka dapat dirumuskan permasalahan sebagai berikut : “ Bagaimana Upaya Penanganan Kekerasan Anak Berbasis Masyarakat?"

\section{PEMBAHASAN}


Anak yang menjadi korban kekerasan sudah seharusnya mendapatkan perlindungan dan penanganan dari berbagai pihak. Dibutuhkan strategi dalam penanganan kekerasan terhadap anak. Strategi yang dilakukan harus mampu mencegah dan menangani tindak kekerasan. Dalam hal ini dibutuhkan kerjasama dari berbagai pihak agar strategi yang dilakukan berjalan secara holistik dan komprehensif. Seperti yang telah disusun oleh UNICEF yaitu strategi penanganan dan pencegahan kekerasan terhadap anak dan perlidungan anak :

1. Supporting parents, caregivers and families

Pendekatan ini berusaha untuk mencegah kekerasan terjadi, mengurangi faktor-faktor yang membuat keluarga rentan terhadap perilaku kekerasan dengan memperkuat keterampilan pengasuhan anak. Menyediakan layanan dukungan lembaga seperti mempersiapkan penyalur pengasuh anak yang terlatih. Home visit yang dilakukan oleh pekerja sosial dan ahli lainnya untuk meningkatkan dan memberikan pengetahuan kepada orang tua dan pengasuh tentang interaksi orang tua dan anak yang positif termasuk penerapan disiplin anti kekerasan dalam pengasuhan anak. Strategi ini berupaya penuh dalam mendukung orang tua, pengasuh, dan keluarga dalam penyediaan informasi, pendidikan dan pengetahuan mengenai "parenting skill". Dengan tujuan mengurangi atau dapat mencegah potensi perilaku kekerasan terhadap anak.

2. Helping children and adolescents manage risk and challenges

Pendekatan ini memberikan keterampilan terhadap anak-anak dan remaja untuk mengatasi dan mengelola risiko kekerasan sehingga dapat membantu anak untuk mengurangi terjadinya kekerasan di sekolah dan masyarakat. Mengajarkan anak berpikir kritis, bertindak asertif, berani menolak dan mengeluarkan pendapat, memecahkan masalah secara kooperatif sehingga mereka dapat melindungi dirinya sendiri dari tindak kekerasan yang terjadi di lingkungannya.

3. Changing attitudes and social norms that encourage violence and discrimination

Pendekatan ini memberikan pengetahuan mengenai cara merespon ketika melihat dan mengalami tindak kekerasan. Memahami ketika ada perbedaan yang terjadi pada norma dan nilai yang berlaku di masyarakat sehingga ketika kita melihat ada perilaku salah, itu dapat dikatakan sebagai tindakan yang wajar atau tidak, dapat di toleransi atau tidak. Mengubah pola pikir masyarakat yang menganggap kekerasan adalah bentuk dari disiplin sehingga dapat membedakan antara norma yang sesuai dan norma sosial yang membahayakan bagi anak. Disini terlihat peran dari masyarakat yang turut menjadi agen perubahan.

4. Promoting and providing support services for children 
Pendekatan ini berupaya menyediakan layanan bagi anak, seperti layanan pengaduan ketika mengalami tindak kekerasan. Memberikan informasi dan bantuan agar anak mendapatkan pemulihan dan tindakan yang tepat. Pemerintah dan masyarakat harus sadar akan pentingnya ketersediaan layanan di lingkungan tempat tinggal.

5. Implementing laws and policies that protect children

Pembuat kebijakan memainkan peran penting untuk melindungi anak-anak. Mereka dapat memastikan bahwa Negara memiliki proses nasional untuk mencegah dan menanggapi kekerasan terhadap anak. Pemerintah harus membangun kerangka hukum yang kuat bahwa implementasi dan monitoring perlu dilakukan.

\section{Carrying out data collection and research}

Peningkatan pengumpulan data nasional dan sistem informasi untuk mengidentifikasi kelompok rentan. Hal ini dilakukan untuk memantau kekerasan yang terjadi pada anak. Mengoptimalkan ketersediaan data tentang isu-isu kekerasan anak (Ending Violence Against Children : Six Strategies for Action, UNICEF : 2014).

Bagi masyarakat, keluarga, atau orang tua diperlukan kebijakan, layanan, sumberdaya, dan pelatihan pencegahan kekerasan pada anak yang konsisten dan terus menerus. Dalam hal ini strategi pencegahan kekerasan terhadap anak meliputi : Pencegahan primer untuk semua orang tua dalam upaya meningkatkan kemampuan pengasuhan dan menjaga agar perlakuan salah atau abuse tidak terjadi, meliputi perawatan anak dan layanan yang memadai, kebijakan tempat bekerja yang medukung, serta pelatihan life skill bagi anak. Yang dimaksud dengan pelatihan life skill meliputi penyelesaian konflik tanpa kekerasan, ketrampilan menangani stress, manajemen sumber daya, membuat keputusan efektif, komunikasi interpersonal secara efektif, tuntunan atau guidance dan perkembangan anak, termasuk penyalahgunaan narkoba; Pencegahan sekunder ditujukan bagi kelompok masyarakat dengan risiko tinggi dalam upaya meningkatkan ketrampilan pengasuhan, termasuk pelatihan dan layanan korban untuk menjaga agar perlakuan salah tidak terjadi pada generasi berikut. Kegiatan yang dilakukan di sini di antaranya dengan melalukan kunjungan rumah bagi orang tua yang baru mempunyai anak untuk melakukan self assessment apakah mereka berisiko melakukan kekerasan pada anak di kemudian hari; Pencegahan tersier dimaksudkan untuk meningkatkan kemampuan pengasuhan yang menjaga agar perlakuan salah tidak terulang lagi, di sini yang dilakukan adalah layanan terpadu untuk anak yang mengalami korban kekerasan, konseling, pelatihan tatalaksana stres.

Pada saat kasus kekerasan pada anak ditemukan, sebenarnya ada masalah dalam pengasuhan anak (parenting disorder). Maka dari itu, strategi pencegahan kekerasan pada 
anak yang mendasar adalah dengan memberikan informasi pengasuhan bagi para orang tua khususnya. Di sisi lain, para orang tua harus diyakinkan bahwa mereka adalah orang yang paling bertanggung jawab atas semua pemenuhan hak anak. Maka semua usaha yang dilakukan dalam rangka mengubah perilaku orang tua agar melek informasi pengasuhan dan hak anak membutuhkan upaya edukasi yang terus menerus. Dengan demikian, pendidikan pengasuhan bagi orangtua sebagai bagian dari strategi pencegahan kekerasan pada anak menjadi sangat penting.

Intervesi sosial merupakan sebuah konsep yang digunakan dan atau dikembangkan di dalam praktik pekerjaan sosial, baik pada pendekatan mikro, masso maupun makro. Intervensi sosial adalah serangkaian kegiatan yang dilakukan secara sistematis dan terencana oleh pekerja sosial dalam pemecahan masalah sosial, peningkatan keberfungsian sosial orang, perluasan aksesibilitas sosial dan pengembangan potensi dan sumber-sumber kesejahteraan (Adi, 2008). Berdasarkan pembahasan di atas, intervensi sosial dalam penanganan kekerasan anak, deskripsikan sebagai berikut:

\section{Prevensi}

Prevensi merupakan serangkaian kegiatan yang ditujukan untuk mencegah terjadinya kekerasan terhadap anak, baik di lingkungan keluarga maupun di lingkungan luar keluarga, seperti di lingkungan sosial dan bermain anak.
Berbagai sistem sumber yang dapat dayagunakan dalam upaya prevensi kekerasan terhadap anak, yaitu:

a. Keluarga

Keluarga yang dimaksud di sini bukan hanya keluarga dalam pengertian keluarga inti (nucleur family), tetapi juga keluarga dalam pengertian keluarga luas (extended family). Keluarga sebagai lingkungan pertama bagi setiap orang, akan memberikan berbagai jenis kebutuhan bagi seseorang, baik ú sikorganis maupun psiko-sosial seperti dukungan emosional, kasih sayang, nasehat, informasi dan perhatian. Selain pemenuhan kebutuhan yang bersifat dometik, kelurga perlu memilihkan teman bagi anak, dan atau memantau pertemanan anak. Prinsipnya anak mendapatkan teman yang aman, nyaman dan mendukung tumbuh kembang. Ikatan kekerabatan perlu aktualisasikan kembali untuk dilembagakan nilai dan norma kekeluargaan dan kepedulian sosial.

b. Institusi Pendidikan

Institusi pendidikan yang dimaksud mencakup sekolah negeri, swasta dan pondok pesantren. Institusi-institusi ini sesuai dengan peranannya telah menyelenggarakan proses pendidikan, baik dalam kaitannya dengan aspek kognitif, afektif maupun psikomotorik anak didik. Namun masih diperlukan materi pelayanan atau mata kuliah yang bermuatan moral dan kepribadian. Anak didik perlu diberikan ruang untuk mendiskusikan hal-hal yang berkaitan dengan kondisi, permasalahan 
dan seluk beluk yang berkaitan dengan kesejahteraan sosial anak.

c. Lembaga Kesejahteraan Sosial

Upaya prevensi dilakukan oleh Lembaga Kesejahteraan Sosial (LKS) lokal, baik yang tumbuh secara alamiah di tingkat lokal (kelompok agama, rukun lingkungan, paguyuban dan lainlain), maupun yang tumbuh dari inisiasi pemerintah (Posyandu, PAUD, Dasa Wisma, Family Care Unit dan lain-lain). Berbagai LKS tersebut memerlukan sebuah media agar potensi dan sumber daya yang dimiliki dapat disinergikan, sehingga memberikan hasil yang lebih optimal. LKS yang ada di akar rumput perlu diberikan kesempatan yang luas sebagai media pertolongan bagi anak, remaja dan orang dewasa yang berpotensi menjadi korban, pelaku atau pemicu terjadinya tindak kekerasan.

\section{d. Institusi Peradilan}

Institusi hukum sesungguhnya merupakan aras ketiga yang diperlukan dalam mewujudkan kesejahteraan anak, serelah keluarga dan masyarakat. Ketiga keluarga dan masyarakat sudah tidak berdungsi dalam mengendalikan perilaku masyarakat, maka diperlukan pendekatan secara hukum melalui instir-tusi peradilan. Permasalahnnya, bahwa hukuman terhadap pelaku tindak kekerasan terhdaap anak, saat ini dinilai belum memberikan efek jera kepada pelaku maupun orang-orang yang potensial menjadi pelaku. Hal ini disebabkan, ada kecenderungan hukuman pidana yang dikenakan terhadap pelaku tindak kekerasan terhadap anak menggunakan referensi KUHP dan belum sepenuhnya menggunakan Undang-Undang Perlindungan Anak. Sistem sumber tersebut ada di tengahtengah masyarakat. Persoalannya, bagaimana sistem sumber tersebut dapat didekatkan dengan dunia anak, sehingga mampu menjadi sistem sumber bagi upaya mencegah tindak kekerasan terhadap anak. Menurut hemat penulis, Kementerian Sosial cq Direktorat Kesejahteraan Sosial Anak perlu mengambil peranan sebagai pihak yang menginisiasi terbentuknya jaringan kerja antara sistem sumber tersebut. Unit kerja ini dapat menawarkan model-model atau skema pencegahan tindak kekerasan terhadap anak kepada jaringan kerja tersebut. Mencegah berarti segala upaya yang dilakukan agar suatu tindakan terentu atau risiko dari suatu tindakan tidak akan terjadi. Sehubungan dengan bahasan dalam tulisan ini, mencegah berarti mengoptimalkan fungsi dan peranan sistem sumber yang ada di masyarakat maupun di instansi pemerintah, sehingga tindak kekerasan terhadap anak tidak terjadi. Selain setiap sitem sumber melaksanakan programprogram secara parsial sesuai dengan tugas pokok dan fungsinya, maka perlu dikembangkan jaringan kerja antara sistem sumber tersebut, misalnya digunakan nama: kelompok kerja atau forum komunikasi atau komunitas peduli anak dan sebagainya. Apapun nama jaringan kerja itu, yang paling 
penting adalah adanya aksi bersama pada sistem sumber tersebut secara terencana dan berkesinambungan.

Berdasarkan kelembagaan yang menjadi sistem sumber prevensi tindak kekerasan terhadap anak, maka strategi yang perlu dikembangkan adalah:

a. Optimalisasi Penyuluhan Sosial

Penyuluhan sosial untuk mencegah tejadinya tindak kekerasan terhadap anak dijadikan gerakan nasional. Sehubungan dengan itu, semua orang secara individu, kelompok dan komunitas memiliki tugas untuk melakukan penyuluhan sosial tersebut. Khusus di lingkungan Kementerian Sosial, terdapat satuan kerja yang memiliki kegiatan yang berkaitan dengan penyuluhan sosial untuk kegiatan prevensi ini, yaitu Pusat Penyuluhan Sosial, Direktorat Kesejahteraan Sosial Anak, Sub Direktorat Ketahanan Sosial Keluarga dan Sub Direktorat Pemberdayaan Keluaraga. Berkaitan dengan itu diperlukan sinergitas pada satuan-satuan kerja tersebut dalam upaya optimalisasi prevensi terjadinya kekerasan terhadap anak.

\section{b. Optimalisasi peranan Lembaga}

Konsultasi Kesejahteraan Keluarag (LK3), Family Care Unit (FCU) dan Lembaga Kesejahteraan Sosial lokal yang diorganisasikan melalaui Wahana Kesejahteraan Sosial Berbasis Masyarakat (WKSBM). Potensi dan sumber kesejahteraan sosial (PSKS) merupakan program yang diinisiasi oleh Kementerian Sosial RI. LK3 memiliki wilayah kerja pada tingkat kabupaten/ kota, sementara itu FCU dan WKSBM memiliki wilayah kerja pada tingkat desa/kelurahan. Pada tahun 2013 ini Direktorat Pemberdayaan Keluarga dan Kelembagaan Sosial mengembangkan kebijakan yang diarahkan untuk mengoptimalkan peranan PSKS tersebut melalui penataan manajemen program. Pada beberapa kali FGD yang dilakukan (yang diikuti penulis), tindak kekerasan terhadap anak ini belum menjadi isu penting. Padahal, posisi PSKS tersebut sangat tersebut, terutama FCU dan WKSBM yang berada di akar rumput, karena mudah dijangkau, murah dan tidak birokratis sebagai penyedia pelayanan sosial bagi masyarakat. Oleh karena itu, ke depan perlu optimalisasi peranan PSKS tersebut.

\section{Rehabilitasi}

a. Sistem Dasar Perubahan

Ada beberapa pihak yang tidak dapat dilepaskan dalam intervensi sosial dalam penanganan kekerasan anak, yang merupakan system dasar perubahan. Pihak-pihak tersebut, yaitu anak, keluarga, teman dekat, masyarakat dan negara/pemerintah serta pekerja sosial, psikolog dan lembaga pelayanan sosial. Pihakpihak tersebut sekaligus menjadi unsur dalam sistem dasar perubahan pada praktik pekerjaan sosial (Suradi, 2005), yaitu:

1) Sistem penerima manfaat (client system), yaitu anak korban kekerasan 2) Sistem sasaran/target (target system), yaitu orang tua/keluarga, teman dekat dan orang-orang 
yang secara sosial-psikologis mampu memberikan dukungan dalam proses rehabilitasi sosial. 3) Sistem kegiatan (action system), yaitu masyarakat, instansi pemerintah sektoral, lembaga pelayanan sosial 4) Sistem pelaksana kegiatan (change agen system), yaitu pekerja sosial profesional, psikolog, dan psikiater. Sistem dasar perubahan tersebut harus dapat diidentiô kasi dengan benar dan tepat. Hal ini dikarenakan keberadaan dan keterlibatan mereka dalam proses rehabilitasi sosial, sangat menentukan tujuan pemulihan pada korban. Dalam hal ini, pekerja sosial profesional merupakan pihak yang memiliki peran utama untuk menentukan sistem dasar tersebut. Pekerja sosial dengan kompetensinya memetakan unsur-unsur yang masuk ke dalam sistem dasar tersebut. Ketidakcermatan dalam menentukan unsur-unsur dalam sistem dasar, maka sangat berpotensi

\section{c. Pengembangan Kebijakan}

Pengembangan kebijakan yang dimaksud di sini adalah upaya memasukkan problema kekerasan pada anak sebagai bagian tidak terpisahkan dari pembangunan nasional. Pada saat ini elemen masyarakat patut memberikan apresiasi kepada pemerintah karena telah memasukkan tindakan kekerasan anak pada RPJM 2010 - 2014. Hal ini menuntut komitmen dan sikap semua pihak dan seluruh elemen bangsa untuk melakukan penanggulangan terjadinya kekerasan pada anak di mana pun dan kapan pun, serta juga menyediakan pusat-pusat pelayanan untuk melakukan rehabilitasi medis maupun psikososial pada anak. Berkaitan dengan itu, maka selain melalui sosialisasi dengan memanfaatkan berbagai media, baik tradisional maupun modern, upaya yang dapat dipetempuh dalam rangka penanggulangan kekerasan terhadap anak adalah:

a. Memasukkan "Perlindungan Anak dari Kekerasan" ke dalam kurikulum yang dimulai dari tingkat sekolah dasar. Diharapkan, anakanak, orang tua dan guru sudah memahami berbagai aspek (sosial, kesehatan, hukum, mental) yang berkaitan dengan kekerasan pada anak.

b. Sebagaimana diuraikan terdahulu, bahwa terjadinya kekerasan pada anak didorong oleh berbagai alasan. Dari berbagai alasan tersebut, faktor kemiskinan merupakan salah satu faktor yang menyumbang pada terjadinya kekerasan terhadap anak. Sehubungan dengan itu, maka upaya penanggulangan kemiskinan hendaknya dipahami dalam kerangka peniadaan tindak kekerasan terhadap anak. Program-program kemiskinan tidak semata-mata meningkatkan pendapatan rumah tangga, tetapi juga meningkatkan harmonisasi sosial di dalam keluarga. Sehubungan dengan itu, di dalam skema penanggulangan kemiskinan diperlukan satu kegiatan bimbingan sosial yang dikaitkan dengan isu-isu kekerasan anak.

c. Pemerintah dan Komisi Penyiaran Indonesia merupakan pihak yang memiliki tugas dan kewenangan untuk melakukan pengendalian terhadap tayangan di media massa. Namun 
demikian, sampai saat ini masih seringkali terjadi penayangan acara atau game yang mempertontonkan tindak kekerasan. Sebagai upaya optimalisasi tugas dan kewenangan KPI, maka perlu ditempuh langkah-langkah, yaitu (1) penataan kelembagaan KPI sebagai organisasi independen, (3) penataan manajemen dan (3) adanya kontrol dari masyarakat atas tugastugas KPI tersebut. Prinsip yang perlu dipegang, bahwa informasi apapun yang ditayangkan melalui media massa haraus berorientasi dan berpihak pada "yang terbaik bagi “.

Terdapat beberapa pilihan strategi yang dapat dilakukan dalam pencegahan dan penanganan masalah kekerasan terhadap anak seperti yang disebutkan di atas. Dalam implementasinya sangat membutuhkan peran aktif dari semua pihak. Selain orang tua, keluarga, pemerintah, masyarakat pun menjadi komponen penting yang turut dilibatkan dalam gerakan pencegahan dan penanganan masalah kekerasan anak. Peran aktif masyarakat setempat yang sadar akan pentingnya pencegahan dan penanganan kekerasan terhadap anak akan memudahkan perancangan strategi apa yang akan dilakukan karena masyarakat turut mengidentifikasi kekuatan dan kelemahan apa saja yang ada di lingkungan mereka.

Adapun kekerasan terhadap anak dilihat dari perspektif ekologi. Bronfenbrenner (1979) dalam studinya mengenai perkembangan anak, menjelaskan adanya lapisan-lapisan sistem ekologi yang mempengaruhi perkembangan anak. Belsky (1980) menjelaskan bahwa faktor-faktor yang mempengaruhi kekerasan pada anak disusun menurut lapisan tertentu. Bagaimana lapisanlapisan tersebut saling mempengaruhi dapat dilihat pada gambar di bawah ini :

\section{Gambar 1. Teori Ekologi}

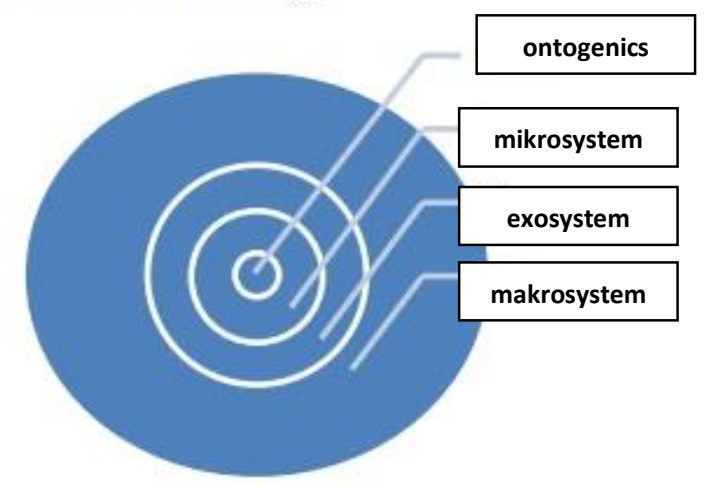

Pada lapisan ontogenics menjelaskan tentang bagaimana faktor individu berkaitan dengan kekerasan pada anak. Faktor-faktor tersebut antara lain masa lalu orangtua, tahap perkembangan orangtua, perasaan terhadap anak, pemahaman terhadap perkembangan anak, dan kesehatan mental orangtua( Zigler dan Hall, 1989). Salah satu isu yang cukup berkembang adalah mengenai sejarah masa kecil orangtua. Orangtua yang mengalami pola asuh dengan kekerasan apakah ketika dewasa akan menjadi pelaku kekerasan. Cicchetti dan Barnett (dalam Scannapieco dan ConnellCarrick, 2005) menyatakan salah satu konstruk yang dapat menjelaskan adalah kelekatan (attachment). Anak yang mengalami kekerasan mengalami kelekatan yang tidak aman atau tipe D (disorganized-disoriented). 
Bowlby (1982) menjelaskan bahwa representasi mental dari bagaimana seseorang menjalin hubungan interpersonal berakar dari kelekatan dengan primary caregiver di masa kecil.Representasi mental meliputi sistem afek, kognitif, dan harapan mengenai bagaimana interaksi social yang ingin dibentuk.

Pada lapisan microsystem adalah mengenai faktor yang berpengaruh secara langsung terhadap anak. Contohnya adalah kondisi keluarga, banyaknya anggota keluarga, hubungan suami-istri, kondisi kesehatan anak( Zigler dan Hall, 1989). Anak-anak dengan karakteristik tertentu seperti lahir dengan kondisi premature, berpenampilan kurang menarik, atau memiliki kekurangan fisik atau mental lebih beresiko untuk menjadi korban kekerasan orangtua. Anak yang mengalami kekerasan adalah anak yang lebih sering menampilkan perilaku negatif dibandingkan kelompok kontrol, anak yang tidak mengalami kekerasan orantua (Burgess dan Conger dalam Scannapieco dan Connell-Carrick, 2005). Kemudian, dalam sistem keluarga, faktor anak dan keluarga saling berinteraksi.Anak dapat menjadi penyebab utama orangtua melakukan kekerasan, namun faktor ini tidak berdiri sendiri.Anak dapat mempengaruhi orangtua tetapi kondisi orangtua juga dapat berpengaruh.

Lapisan exosystem mengaitkan anak dan keluarga pada sistem yang lebih luas. Faktor-faktornya antara lain keluarga besar, status social ekonomi, komunitas, dan system pendukung lainnya. Sistem pendukung menjadi sumber stress bagi orangtua yang dapat mempengaruhi pola asuh orang tua( Zigler dan Hall, 1989). Hubungan dengan tetangga juga dapat mempengaruhi perilaku kekerasan terhadap anak.

Lapisan macrosystem adalah lapisan terluar yang terus-menerus saling berinteraksi dengan lapisan ontogenics, microsystem, dan exosystem. Faktor-faktor yang masuk kategori ini adalah sikap masyarakat terhadap kekerasan,harapan masyarakat terhadap pola pendisiplinan di rumah dan sekolah, dan kekerasan yang terjadi di masyarakat(Zigler dan Hall, 1989).

Lapisan-lapisan dalam pendekatan ekologi tersebut saling berkaitan satu sama lainnya. Sehingga dalam penanganan masalah kekerasan terhadap kekerasan perlu dilakukan secara holistik dan keterlibatan semua pihak yang ada di lingkungan sekitar.

\section{PENUTUP}

Kekerasan terhadap anak menjadi fenomena yang tidak habisnya. Masih banyak kasus kekerasan anak yang masih belum ditangani secara optimal karena masih adanya keengganan dari pihak keluarga korban untuk melaporkan tindak kekerasan tersebut. Mata rantai tindak kekerasan terhadap anak perlu diputus mata rantainya karena anak dengan masa lalu mengalami kekerasan akan ada kencenderungan menimbulkan trauma untuk 
melakukan kekerasan pula ketika mereka dewasa nanti.

Anak yang menjadi korban kekerasan perlu ditangani secara khusus karena korban kekerasan akan mengalami trauma baik fisik maupun mental. Penanganan kekerasan terhadap anak memerlukan kerjasama dari orang tua, keluarga, masyarakat dan pemerintah. Oleh karena itu upaya penanganan kekerasan anak berbasis masyarakat perlu dilakukan untuk memutus mata rantai tindak kekerasan.

Selain itu upaya pencegahan menjadi bagian penting dari upaya memutus mata rantai tindak kekerasan tersebut. Upaya tersebut dapat dilakukan melalui dari lingkungan sosial yang paling awal dan paling dekat yaitu keluarga, kerabat, dan hingga seterusnya meluas ke masyarakat serta pengendalian media sosial dan media massa oleh pemerintah. Perlu kesadaran bersama, bahwa tindak kekerasan sudah merupakan kejahatan yang sangat luar biasa yang dapat mengganggu tumbuh kembang anak di masa yang akan datang, serta akan berimbas pada terganggungnya proses pendidikan dan pengasuhan anak dalam institusi-institusi sosial yang ada.

\section{DAFTAR PUSTAKA}

\section{Buku- buku}

Adi, Isbandi Rukminto. 2008. Intervensi Komunitas Pengembangan Masyarakat Sebagai Upaya
Pemberdayaan Masyarakat. Jakarta: Rajawali Pers

Buku Panduan Pelatihan tentang Deteksi Dini dan Penatalaksanaan Child Abuse and Neglect untuk para Profesional Kesehatan.

Budi Keliat, Anna. 1998. Penganiayaan Dan Kekerasan Pada Anak. Jakarta: FKUI

Cicchetti, Dc\& Carlson, V. Child Maltreatment: Theory and Research on The Causes and Consequence of Child Abuse and Neglect. Cambrige University Press: Cambridge.

Huraerah, Abu. 2012. Kekerasan terhadap Anak. Bandung: Nuansa Cendekia Departemen

Nelson, S. 1995. Tumbuh Kembang Anak. Jakarta: EGC.

Soeroso, Moerti Hadiati. 2010. Kekerasan dalam rumah tangga. Jakarta: Sinar Grafika

Suhendi, Hendi dan Wahyu Ramdani 2001. Pengantar studi Sosiologi Keluarga. Bandung: Pustaka Setia

Susana, T. 2007. Mempertimbangkan Hukuman Pada Anak. Yogyakarta: Kanisius.

Swoden, L.A. 2009. Buku Saku Keperawatan Pediatri. Jakarta: EGC.

Supeno, H. 2010. Kriminalisasi Anak. Jakarta: PT. Gramedia Pustaka Utama.

Tower,Cynthia Crosson .2002. Child Abuse and Neglect : Fifth Edition. Unites States of America.

Undang-Undang Nomor 23 Tahun 2002 Perlindungan Anak.

Wong, D.L. 2009. Buku Ajar Keperawatan Pediatrik. Jakarta: EGC.

Laporan Bulanan KPAI Kasus Pengaduan Anak Berdasarkan Klaster Perlindungan Anak : Kasus dan Korban Kekerasan Terhadap Anak. 
Zigler, E \& Hall, N. W. 1989. Physical child abuse in America: past, present, and future. In

\section{E-book}

Ending Violence Against Children : Six Strategies for Action, UNICEF : 2014

For Every Child, A Fair Chance, UNICEF : 2015

\section{Website}

http://nasional.kompas.com/read/2016/02/14/ 14175531/Menteri.Yohana.Terus.Me ningkat.Kekerasan.pada.Anak.bak.Fe nomena.Gunung.Es (diunduh pada tanggal 25 Mei 2016, pukul 20.00 WIB)

http://health.liputan6.com/read/2460844/kakseto-kasus-kekerasan-anak-terusmeningkat (diunduh pada tanggal 25 Mei 2016, pukul 20.20 WIB)

http://nasional.news.viva.co.id/news/read/655 240-kpai--kekerasan-terhadap-anakmeningkat-tajam (diunduh pada tanggal 25 Mei 2016, pukul 21.00 WIB) 